\title{
POTENSI KOMBINASI KONSORSIUM MIKROORGANISME INDIGEN DAN LIMBAH BUDIDAYA PADI DALAM MENINGKATKAN PERTUMBUHAN DAN PRODUKSI TANAMAN SAWI
}

\section{THE POTENCY OF INDIGENOUS MICROORGANISM CONSORTIUM COMBINED WITH THE RICE CULTIVATION WASTE TO RAISE GROWTH AND YIELD OF MUSTARD}

\author{
Suslam Pratamaningtyas ${ }^{1)}$, Tri Wardhani ${ }^{1)}$, Suprihana ${ }^{\text {( }}$, dan Ekky Zanuar ${ }^{1)}$ \\ ${ }^{1}$ Fakultas Pertanian, Universitas Widyagama Malang \\ Email: suslampratama@gmail.com
}

\begin{abstract}
ABSTRAK
Tujuan penelitian ini adalah untuk mengetahui pengaruh aplikasi konsorsium mikroorganisme indigen yang dikombinasikan dengan penambahan limbah budidaya padi berupa jerami terfermentasi, sekam bakar dan abu sekam. Penambahan konsorsium mikroorganisme dalam 3 tingkat kerapatan $10^{5}, 10^{6}, 10^{7} \mathrm{CFU}$ yang dikombinasikan dengan 3 macam bahan organik berupa limbah budidaya padi dimaksudkan untuk meningkatkan pertumbuhan dan produksi tanaman uji (Brassica juncea). Penelitian menunjukkan hasil yang tidak berbeda nyata. Hal ini kemungkinan disebabkan oleh waktu penelitian yang kurang panjang, umur tanaman uji yang hanya 1 bulan, sehingga belum ada interaksi positif yang terjadi antara penambahan bahan organik dengan konsorsium mikroorganisme indigen yang diberikan.
\end{abstract}

Kata kunci: konsorsium, indigen, CFU, limbah, terfermentasi

\begin{abstract}
The purpose of this study was to determine the effect of the application of consortium of indigenous microorganisms combined with the addition of rice cultivation waste in the form of fermented straw, fuel husk and husk ash. Addition of consortium of microorganisms in 3 levels of density 105, 106, 107CFU combined with 3 kinds of organic material in the form of rice cultivation waste is intended to increase growth and production of test plants (Brassica juncea). Research shows results that are not significantly different. This is probably due to the lack of length of the study time, the age of the test plant which is only 1 month, so there has been no positive interaction between the addition of organic matter and the consortium of indigenous microorganisms given.
\end{abstract}

Keywords: consortium, indigen, CFU, waste, fermented 


\section{PENDAHULUAN}

Mikroorganisme indigen adalah semua jenis jasad mikro/renik yang telah bertahan hidup dalam suatu tempat/lokal selama puluhan atau bahkan ratusan generasi. Mikroorganisme ini telah beradaptasi dengan sangat baik pada lingkungannya, baik lingkungan biologis maupun lingkungan fisiknya. Pada umumnya mikroorganisme indigen mempunyai potensi sebagai agen biodegradasi, bioleaching, biocomposting, fiksasi nitrogen, pelarut fosfat, dan penghasil hormon tumbuh tanaman.

Praktek pertanian selama ini, yang mengaplikasi bahan-bahan kemikalia pertanian secara intensif dan telah dilakukan selama beberapa dekade, telah mengindikasikan kerusakan lingkungan yang makin meningkat. Kerusakan lingkungan meliputi lingkungan tanah, lingkungan perairan dan polusi udara yang berdampak pada pemanasan global. Oleh karena itu, para peneliti terutama pemerhati pertanian dan masalah lingkungan telah bersepakat bahwa mikroorganisme dapat diandalkan untuk dimanfaatkan sebagai agen biologis untuk memperbaiki, atau minimal mempertahankan kualitas lingkungan untuk keberlanjutan kehidupan di bumi.

Kerusakan lingkungan tanah berakibat terhambatnya pertumbuhan tanaman budidaya karena unsur-unsur makro yang dibutuhkan oleh tanaman seperti nitrogen dan fosfat menjadi tidak tersedia. Berdasarkan beberapa hasil penelitian yang telah dilakukan, disimpulkan bahwa mikroorganisme dapat berperan sebagai biopestisida, biofertilizers, maupun sebagai agen bioremediator (Chatzipavlidis, et al., 2013).

Dalam budidaya padi, jerami merupakan bagian terbesar yang sampai saat ini belum dimanfaatkan secara maksimal. Dari setiap hektar lahan sawah, produksi jerami dapat mencapai 12-15 ton per panen (Ahmad dan Nashir, 2008). Padahal penelitian yang dilakukan oleh Kusumawardhani dan Tyas (2015), membuktikan bahwa penggunaan kompos jerami padi mampu menurunkan penggunaan pupuk anorganik sebesar 125 kilogram. Penambahan kompos jerami padi mampu meningkatkan hasil panen sebesar 33\%. Hal ini dikarenakan kompos jerami padi meminimalisir pelepasan Nitrogen dalam tanah sehingga pasokan Nitrogen 
dalam tanah meningkat dan struktur tanah menjadi baik.

Selain jerami, sekam padi juga merupakan byproducts yang belum dimanfaatkan dengan baik. Kandungan silikat yang tinggi membuat bahan ini membutuhkan waktu cukup lama untuk terdekomposisi dengan sempurna. Oleh karena itu bahan ini banyak digunakan oleh para pedagang bunga sebagai media tanam, baik berupa sekam segar maupun sekam bakar.

Menurut Suharno (1979), sekam bakar mengandung beberapa unsur penting yakni kadar air $(9,02 \%)$, protein kasar $(3,03 \%)$, lemak $(1,18 \%)$, serat kasar $(35,68 \%)$, abu $(17,17 \%)$, dan karbohidrat dasar $(33,71)$. Selanjutnya komposisi kimia sekam padi menurut DTC-IPB sekam mengandung karbon (zar arang) sebesar 1,33\%, hidrogen sebesar $1,54 \%$, oksigen $33,64 \%$ dan silica sebesar 16,98\%. Berkaitan dengan pemanfaatan kompos jerami dan abu sekam, hasil penelitian Pane et al. (2014) pada tanaman jagung, menunjukkan bahwa kompos jerami padi berpengaruh nyata dalam meningkatkan C-organik, P-tersedia, tinggi tanaman, berat kering tanaman, serapan $\mathrm{N}$ dan serapan $\mathrm{P}$, tetapi tidak meningkatkan $\mathrm{pH}$ dan N-total tanah, sedangkan pemberian abu sekam padi berpengaruh nyata dalam meningkatkan Corganik dan serapan $\mathrm{N}$ tanaman, namun tidak berpengaruh nyata dalam meningkatkan $\mathrm{pH}, \mathrm{P}$-tersedia, $\mathrm{N}$-total tanah, tinggi tanaman, berat kering tanaman dan serapan $\mathrm{P}$ tanaman

Abu sekam memiliki fungsi mengikat logam berat. Selain itu sekam berfungsi untuk menggemburkan tanah sehingga bisa mempermudah akar tanaman menyerap unsur hara di dalamnya, oleh karena itu bagaimanapun juga masih tetap diperlukan campuran media lain dalam media tanaman tersebut, terutama campuran kompos. Abu sekam padi mengandung beberapa unsur hara yaitu P 0,20\%; K 1,21\%; Ca dan $\mathrm{Mg}$ (mg/100g) 0,26 dan 0,12 (Raihan et al., 2005).

\section{METODE PENELITIAN}

Penelitian dilaksanakan pada bulan Juni sampai September 2018 di green house dan laboratorium kampus III Fakultas Pertanian Universitas Widyagama Malang yang berlokasi di Kelurahan Mojolangu Kecamatan Lowokwaru Kota Malang pada ketinggian tempat 470 meter di atas 
permukaan laut, suhu rata-rata $24^{\circ} \mathrm{C}-25^{\circ} \mathrm{C}$, curah hujan 2000-3000 mm/tahun

Alat percobaan meliputi nampan semai, tong fermentasi, polybag dengan ukuran diameter $20 \mathrm{~cm}$, gunting, cetok, cangkul, timbangan digital, tabung gelas cawan petri, dan alat tulis.

Bahan percobaan meliputi benih sawi, media tanam yaitu: (jerami terfermentasi, sekam bakar, abu sekam), gula dan substansi mikroorganisme indigen.

Penelitian ini menggunakan Rancangan Acak Kelompok (RAK) dengan 2 faktor yang disusun secara faktorial. Faktor pertama adalah penambahan limbah budidaya padi (kode B) dengan 4 aras yaitu: $\mathrm{B}_{0} /$ tanpa penambahan limbah, $\mathrm{B}_{1} /$ jerami terfermentasi, $\mathrm{B}_{2} /$ sekam bakar dan $\mathrm{B}_{3} / \mathrm{abu}$ sekam. Faktor kedua adalah aplikasi konsorsium mikroba indigen (kode $\mathrm{M}$ ) dengan 4 aras yaitu $\mathrm{M}_{0} /$ tanpa aplikasi konsorsium mikroorganisme indigen, $\mathrm{M}_{1}$ /aplikasi konsorsium mikroba indigen dengan kerapatan $10^{7} \mathrm{CFU}, \mathrm{M}_{2} /$ aplikasi mikroba indigen $10^{6} \mathrm{CFU}$, dan $\mathrm{M}_{3} /$ aplikasi mikroba indigen $10^{5}$. Dengan demikian ada 16 kombinasi perlakuan yang diulang 3 kali.

Dosis limbah budidaya padi yang diberikan adalah 40gram/polybag, sedangkan dosis substansi konsorsium mikroorganime indigen tergantung umur tanaman percobaan, di mana volumenya makin meningkat denga bertambahnya umur tanaman.

\section{a. Fermentasi Jerami}

Pengomposan jerami padi memerlukan perlakuan tertentu, karena jerami padi banyak mengandung lignin $(16,45 \%)$ dan rasio $\mathrm{C} / \mathrm{N}$ di atas 50, sehingga sulit terdegradasi dan membutuhkan waktu pengomposan relatif lama. Dalam pengomposan bahan organik, kecepatan dekomposisinya sangat mempengaruhi kecepatan tersedianya unsur hara (Martajaya, 2010). Dalam penelitian ini jerami diperoleh dari petani padi di Pasuruan yang biasa mengomposkan limbah jeraminya.

\section{HASIL DAN PEMBAHASAN}

Pada penelitian ini kombinasi pemberian bahan pembenah tanah jerami terfermentasi, sekam bakar, dan abu sekam tidak berpengaruh nyata terhadap pertumbuhan panjang daun, lebar daun, jumlah daun, dan berat segar total tanaman sawi. Begitu juga aplikasi larutan 
konsorsium mikroba indigen dengan kerapatan koloni $10^{5}, 10^{6}$, dan $10^{7}$ tidak berpengaruh nyata pada tanaman yang sudah dewasa. Dari hal tersebut di mana $\mathrm{B}_{0}$ (kontrol) tanpa bahan pembenah tanah justru lebih baik dari bahan-bahan yang lainnya, diduga media tanam (tanah) tersebut mempunyai kandungan unsur hara yang bagus, sehingga tanaman sawi dapat tumbuh dengan maksimal. Sedangkan pada bahan organik $\mathrm{B}_{1}, \mathrm{~B}_{2}$, dan $\mathrm{B}_{3}$ mendapatkan nilai rendah diduga karena bahan organik yang diaplikasikan masih membutuhkan proses dekomposisi atau penguraian dalam waktu yang cukup lama sehingga tanaman sawi tidak mendapat nutrisi yang maksimal.

Kerapatan mikroorganisme indigen $10^{5}$ CFUsecara visual menunjukan pengaruh lebih baik di bandingkan kerapatan mikroorganisme $10^{6}, 10^{7}$, dan kontrol (0). Namun aplikasi konsorium mikroorganisme indigen tidak berpengaruh nyata terhadap variabel pertumbuhan tanaman yaitu jumlah daun, panjang daun, dan lebar daun. Hal tersebut disebabkan karena pada benih masih ada cadangan makanan sedangkan pada media tanam sama sekali tidak ada tambahan nutrisi tanah selain substansi mikroorganisme indigen dengan berbagai kerapatan dan bahan organik yang belum cukup terdekomposisi. Dengan demikian aplikasi substansi mikroorganisme indigen seyogyanya didampingi nutrisi atau pupuk sintetis yang cukup untuk menghasilkan pertumbuhan tanaman yang maksimal.

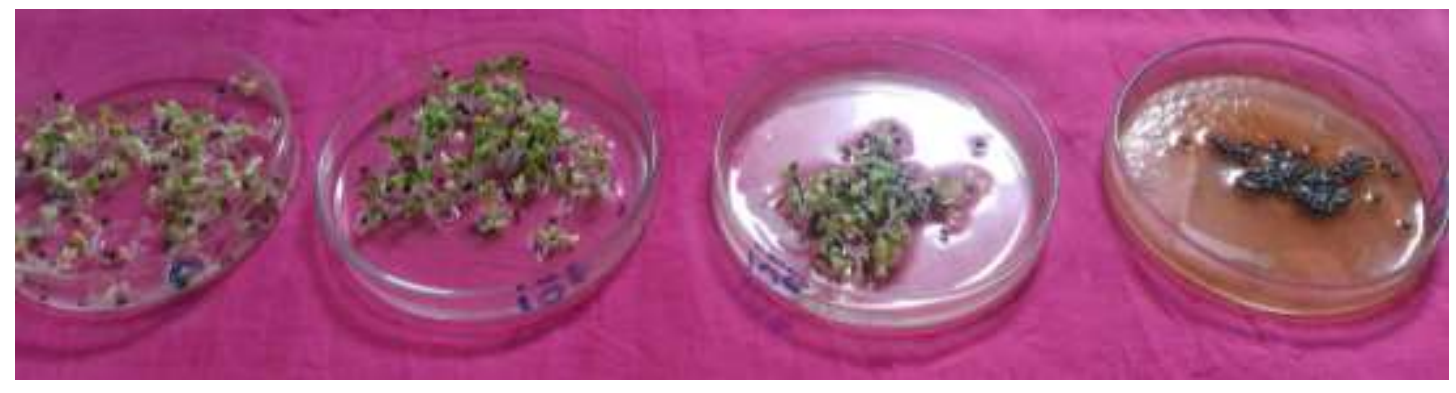

Gambar 1. Perkecambahan benih sawi dengan penambahan konsorsium mikroorganisme indigen 
Namun demikian, pada uji pendahuluan aplikasi MOL pada pertumbuhan kecambah benih sawi, menunjukan indikasi yang paling baik pada aplikasi MOL $10^{5}$ (Gambar 1.)

Menggabungkan jerami padi dan bahan organik lainnya dalam pengomposan telah banyak dilakukan dan beberapa hasil penelitian menunjukkan adanya perubahan positif dalam memperbaiki sifat tanah tersebut. Secara umum, penggunaan pupuk organik yang bersumber dari jerami pada musim tanam pertama belum memberikan pengaruh yang nyata terhadap pertumbuhan dan komponen hasil padi, namun ada kecenderungan pertumbuhan dan hasil tanaman yang menggunakan bahan organik lebih tinggi dibanding tanpa pupuk organik baik secara tunggal maupun interaksinya dengan pupuk $\mathrm{N}$, $\mathrm{P}$, dan $\mathrm{K}$ (Arafah dan Sirappa, 2003).

Grafik berikut menggambarkan pengaruh penambahan beberapa macam limbah budidaya padi yang diujikan dan konsorsium mikroorganisme indigen dalam beberapa tingkat kerapatan terhadap perkembangan jumlah daun tanaman sawi.

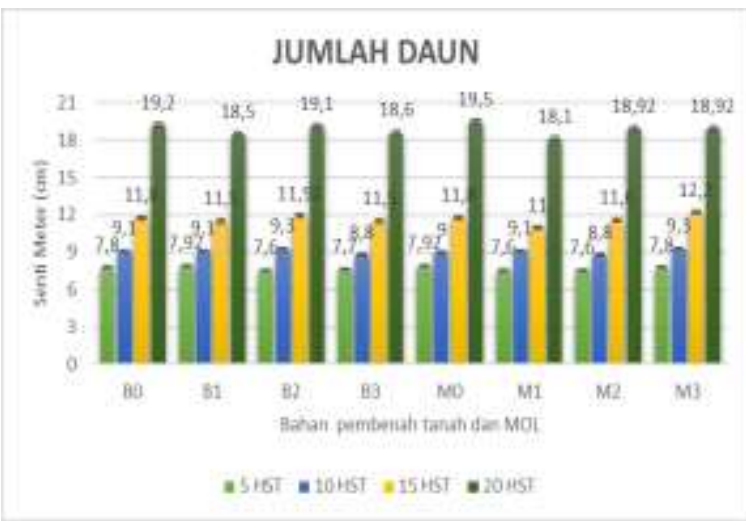

Gambar 2. Pengaruh Berbagai Limbah Budidaya Padi dan Konsorsium Mikroorganisme Indigen pada Jumlah Daun Tanaman Sawi

Dari analisis ragam yang dilakukan, menunjukan tidak adanya interaksi antara 2 faktor perlakuan yang diberikan terhadap variabel jumlah daun tanaman. Hal ini mungkin disebabkan oleh faktor genetik bawaan varietas yang digunakan sebagai tanaman uji, yaitu bahwa jumlah daun merupakan sifat kualitatif yang tidak banyak terpengaruh oleh perbedaan kondisi lingkungan dan berbeda dengan sifat kuantitatif, yang sangat dipengaruh oleh perubahan faktor lingkungan, baik lingkungan fisik maupun kimia dan biologis.

Sedangkan pada pengamatan berat segar tanaman (Tabel 1.), perlakuan yang memberikan pengaruh berat segar paling tinggi terdapat pada perlakuan B2 atau 
penambahan bahan organik yang berasal dari sekam bakar. Penambahan sekam bakar dari hasil penelitian yang dilakukan mampu menambah bobot segar dari tanaman. Hal ini dikarenakan sekam padi merupakan media yang cukup baik bagi tanaman dimana sekam padi ini mengandung unsur hara $\mathrm{N}$ sebanyak $1 \%$ dan K 2\%. Sekam padi juga dapat dipakai sebagai media pengganti humus pada tanaman. Sekam padi mempunyai beberapa fungsi antara lain mampu mengikat (menahan) air, memberikan drainase dan aerasi baik bagi tanaman, dan dapat mempertahankan kelembaban tanah di sekitar akar tanaman (Wuryaningsih dan Herlina, 1993).

Tabel 1. Pengaruh perlakuan terhadap berat segar tanaman saat panen

\begin{tabular}{|c|c|}
\hline Perlakuan & $\begin{array}{c}\text { Berat Segar Total } \\
\text { Tanaman }(\mathrm{g})\end{array}$ \\
\hline Bahan Organik & Panen \\
\hline B0 & 169.8475 \\
\hline B1 & 157.9342 \\
\hline B2 & 175.8942 \\
\hline B3 & 166.8358 \\
\hline MOL & \\
\hline M0 & 182.8025 \\
\hline M1 & 156.3033 \\
\hline M2 & 161.6592 \\
\hline M3 & 169.7467 \\
\hline
\end{tabular}

Tidak signifikannya pengaruh penambahan bahan organik limbah budidaya padi yang diharapkan dapat memperbaiki struktur tanah sehingga dapat meningkatkan produksi tanaman uji, diduga disebabkan karena kurang sempurnanya proses fermentasi atau karena jangka waktu penelitian yang kurang panjang sehingga dampak aplikasi bahan organik pembenah tanah yang diberikan belum menunjukan hasil signifikan. Sedangkan tidak signifikannya perlakuan aplikasi konsorsium mikroorganisme indigen terhadap pertumbuhan dan produksi tanaman uji, dapat pula disebabkan karena dalam jangka waktu pelaksanaan penelitian ada beberapa hari di mana suhu udara menjadi sangat rendah (musim bedhidhing), yang mungkin sangat berpengaruh terhadap aktivitas mikroorganisme yaitu mikroorganisme menjadi in-aktif.

\section{KESIMPULAN}

\section{Kesimpulan}

Dari hasil penelitian yang telah dilakukan dapat ditarik beberapa kesimpulan sebagai berikut:

1. Tidak ada interaksi antara perlakuan beberapa macam bahan organik limbah 
budidaya padi dan aplikasi substansi mikroorganisme indigen terhadap pertumbuhan dan produksi tanaman sawi hijau.

2. Beberapa jenis bahan organik limbah budidaya padi dengan dosis 40 gram per polybag atau per tanaman tidak berpengaruh nyata terhadap pertumbuhan dan produksi tanaman sawi hijau.

3. Aplikasi substansi mikroorganisme lokal dalam beberapa tingkat kerapatan yang diberikan dalam penelitian ini tidak memberikan pengaruh yang signifikan terhadap pertumbuhan dan produksi tanaman sawi hijau.

\section{Saran}

Berdasarkan hasil penelitian yang telah dilakukan dengan judul seperti pada topik penelitian ini, maka dapat diberikan beberapa saran sebagai acuan untuk penelitian yang akan dilakukan kemudian, yaitu:

1. Penelitian untuk menguji perlakuan penambahan bahan organik terhadap produktivitas tanah maupun tanaman sebaiknya dilakukan dengan menggunakan tanaman uji yang mempunyai umur cukup panjang guna melihat pengaruh yang lebih signifikan.
2. Untuk penelitian yang berkaian dengan aplikasi mikroorganisme dengan harapan dapat meningkatkan pertumbuhan maupun produksi tanaman dan produktivitas lahan, sebaiknya dilakukan di dalam ruangan yang dapat dikontrol dengan cukup baik, karena mikroorganisme sangat peka terhadap perubahan kondisi lingkungan.

\section{DAFTAR PUSTAKA}

Ahmad, M. dan Nashir. 2008. Pembuatan Jerami Fermentasi. Lembar informasi pertanian (Liptan) IP2TP Mataram No.02/Liptan/2000. Instalasi Penelitian dan Pengkajian Teknologi Pertanian. Mataram.

Arafah dan M.P. Sirappa. 2003. Kajian Penggunaan Jerami dan Pupuk N, P, dan K pada Lahan Sawah Irigasi. J. Ilmu Tanah dan Lingkungan. 4(1): 1524.

Chatzipavlidis, I., I. Kefalogianni, A. Venieraki and W. Holzapfel. 2013. Commission on Genetic Resources for Food and Agriculture. Status and Trends of the Conservation and Sustainable Use of Microorganisms in Agroindustrial Processes.

Kusumawardhani, R. dan T. A. Tyas. 2015. Pemanfaatan Jerami Padi Menjadi Pupuk Organik dan Wahana Budidaya Belut oleh Masyarakat Desa Wonorejo. Seminar Nasional 
Universitas PGRI Yogyakarta. ISBN 978-602-73690-3-0 198.

Martajaya, M. 2010. Metode Budidaya Organik Tanaman Jagung Manis di Tlgomas, Malang. Jurnal Pembangunan dan Alam Lestari. 1(1): 1-4.

Pane, M.A., M. M. B. Damanik, B. Sitorus. 2014. Pemberian Bahan Organik Kompos Jerami Padi dan Abu Sekam Padi dalam Memperbaiki Sifat Kimia Tanah Ultisol serta Pertumbuhan Tanaman Jagung. Agroekotekonologi. 2(4): 1426-1432. ISSN No. 23376597.

Raihan, S., Hairunsyah, A. Noor, dan Y. Raihana. 2005. Peranan Beberapa Macam Bahan Organik dan Pupuk Kalium terhadap Pertumbuhan dan Hasil Jagung di Lahan Kering. http://www.google.com/scholar, diakses pada tanggal 10 Agustus 2017.

Suharno. 1979. Sekam Padi sebagai Sumber Energi Alternatif. www.smallcrab.com/. Diakses tanggal 12 April 2018.

Wuryaningsih, S. dan D. Herlina. 1993. Komposisi Media dan Pemupukan pada Tanaman Hias Pot Spathiphyllum. Buletin Penelitian Tanaman Hias. 1(1): 113-123. 